\title{
Pre-service primary school teachers' metacognitive awareness and beliefs about mathematical problem solving
}

\author{
Alper Yorulmaz ${ }^{1}$, Hümeyra Uysal², Halil Çokçalışkan ${ }^{1 *}$ \\ ${ }^{1}$ Faculty of Education, Mugla Sitkı Kocman University, Turkey \\ ${ }^{2}$ Institute of Education Science, Marmara University, Turkey \\ *Corresponding author: $\underline{\text { hcokcaliskan@mu.edu.tr }}$
}

\begin{tabular}{l} 
ARTICLE INFO \\
\hline Article history: \\
Received: 4 May 2021 \\
Revised: 27 June 2021 \\
Accepted: 29 June 2021 \\
Published online: 20 July 2021 \\
Published regularly: July 2021
\end{tabular}

Keywords:

Metacognitive awareness, mathematical problem solving, beliefs, pre-service primary school teachers, primary education

\section{ABSTRACT}

Metacognitive awareness is a variable that is thought to affect beliefs in problem solving. When the literature is examined, it is seen that the studies mostly focus on metacognitive awareness and problem solving skills. Therefore, the aim is to determine pre-service primary school teachers' metacognitive awareness and beliefs in mathematical problem solving. In this study, it is thought that it will contribute to the researches that will be carried out regarding the investigation of the relationship between metacognitive awareness and beliefs about problem solving and its implementation with pre-service primary school teachers. The study, designed as the correlational survey model, included a total of 284 preservice primary school teachers attending a university in the Aegean Region of Turkey. The data were collected with the "Metacognitive Awareness Inventory" and the "Scale of Beliefs about Mathematical Problem Solving". In the analysis, descriptive statistics, difference test, correlation and regression analyses were used. As a result, the preservice primary school teachers' metacognitive awareness was found to be high and their beliefs about mathematical problem solving were found to be medium. While metacognitive awareness was found to be not varying significantly by gender, beliefs about mathematical problem solving were found to be varying significantly by gender in favor of the male pre-service teachers. Moreover, a medium and significant correlation was found between metacognitive awareness and beliefs about mathematical problem solving. It was also found that metacognitive awareness explained $13 \%$ of the variance in the dependent variable of beliefs about mathematical problem solving.

(C) 2021 Universitas Muhammadiyah Surakarta

\section{Introduction}

Knowing the situation of application and using calculation skills are involved in the mathematical problem solving process (Montague, Applegate \& Marquard, 1993). In mathematical problem-solving process, individuals should understand and interpret the information contained in the problem, make a choice regarding the operations they will perform, and decide on the application (Özkubat \& Özmen, 2020). Since the problem solving process is expressed as a decision-making and implementation process, the individual who will be engaged in this process must have a belief in mathematical problem solving. The concept of metacognition has an important place in the formation of belief in

To cite this article:

Yorulmaz, A., Uysal, H., \& Çokçaliskan, H. (2021). Pre-service primary school teachers' metacognitive awareness and beliefs about mathematical problem solving. JRAMathEdu (Journal of Research and Advances in Mathematics Education), 6(3), 239-259. https://doi.org/10.23917/jramathedu.v6i3.14349 
mathematical problem solving in individuals. Metacognition includes the skills required for an individual to be aware of the process of completing a task successfully, monitor himself/herself, and control his/her own performance (Flavell, 1979). Metacognitive awareness includes the individual's knowledge about a task and how, when and where to perform the task (Schraw ve Moshman, 1995). In other words, the knowledge to be possessed about metacognitive skills is expressed as metacognitive awareness. Knowledge and skills involved in the individual's metacognitive awareness affect behaviors in mathematical problem solving process (Gelbal, 1991). Beliefs in problem solving have an important place in terms of influencing behaviors. In the current study conducted on the basis of this conceptual framework, mathematical problem solving beliefs are explained with metacognitive awareness, and findings which will reveal the relationship and effect between these concepts will be explained.

\section{Mathematical problem solving}

Mathematics is an integral part of life. Since mathematics is a discipline utilized by many fields such as health, engineering, agriculture and industry as well as mathematics being directly related to the problem solving skill of the individual. The problem is defined as a situation that physically or cognitively disturbs the individual (Karasar, 2009), prevents the individual from achieving his/her goal (Çubukçu, 2011), does not have a known way of solution (Smith \& Kosslyn, 2014), but that needs to be solved (Polya, 1981; Posamentier \& Krulik, 2016). Human beings are faced with many problems both in social and academic life from birth to death. Through mathematics, individual not only acquires problem solving skills, but also prepares for the solution of problems they may encounter in daily life (Altun, 2008; Özsoy, 2014). Thus, the individual can adapt to the social, scientific and technological developments of social life.

Each problem has a unique nature, but various criteria come to the fore in defining a situation as a problem. Grouws (1996) defines a mathematical problem as "a problem that needs to be found or shown, but how to find or show is not clear at a glance with available information" (as cited in Kayan \& Çakıroğlu, 2008). Mathematically, problems should be interesting, intriguing, and suitable for justification and explanation (Van De Walle, Karp \& Bay-Williams, 2016). In addition, while a situation is a problem for one person, it may not be a problem for the other person. In order to qualify the situation faced as a problem, the situation must create difficulties for the individual, it needs to be resolved, and the individual is not prepared for the situation and should not have encountered the situation before (Dağll, 2004). If the situations encountered do not have these characteristics, they can be mathematically described as questions or exercises.

Problem solving can be seen as the work of overcoming the difficult situation expressed in the definition of the problem. It is the state of coping with the problem (Heppner \& Peterson, 1982). The problem creates cognitive dissonance in the individual and the re-establishment of cognitive balance is achieved through the problem-solving process (Baki, 2018). Problem solving is a mental process that requires individuals to produce appropriate solutions to the problem based on their own knowledge, experience and skills (Lai \& Yang, 2011). It requires a complex performance between emotional and social domains (Morgan \& Williams, 2007). Therefore, training individuals with advanced problem solving skills is seen as an important step for social development.

Problem solving skills are among the basic skills that should be imparted in curriculums for training qualified individuals. Starting from basic education, the individual's gaining problem solving skills will have a positive effect on his/her academic and social life in the future (Baykul, 2016). Problem solving is a way of thinking that can be taught and used as a teaching method (Posamentier \& Krulik, 2016). Seen from this 
perspective, it can be thought that primary school teachers who are responsible for educating students in the first step of compulsory education must have developed problem solving skills in order to be effective role models for the students they will train.

It can be said that it would be beneficial to determine the factors affecting problem solving skills first and then, to reveal the relations between these factors in order to develop problem solving skills. Many factors come to the fore in terms of the development of problem solving skills, from factors to be examined at national level such as the structure of the education system (Izgar, Gürsel, Kesici \& Negiș, 2004) to individual factors such as maturity level, social-cultural environment, motivation (Silik, 2016). These factors can be classified as experiential, cognitive and affective.(Charles \& Lester, 1982). In addition, it is possible to classify those that affect the problem solving process as resources, strategies, metacognition and belief (Schoenfeld, 1985). In this context, beliefs in mathematical problem solving will be focused on.

\section{Beliefs about mathematical problem solving}

Learning is a complex concept dealt with in terms of cognitive, affective and behavioral factors. When the sub-factors of this broad classification are examined, the concept of belief emerges an important factor affecting the learning-teaching process (Pajares, 1992; Thompson, 1992). "Beliefs are expressed as internal assumptions or propositions that determine how the individual perceives, interprets and acts towards any event, phenomenon, and person or object encountered in life, and that are assumed to be true without any doubt by the individual." (Deryakulu, 2004). Problem-solving beliefs are value judgments made up of a person's past mathematical experiences (Raymond, 1997). In this respect, it can be thought that an individual is necessary to experience positive judgments in order to develop positive beliefs about mathematical problem solving.

The individual first encounters with academic mathematical problem solving at the primary school level. Beliefs formed as a result of positive experiences about mathematics in the education process positively support both mathematical problem solving skills and academic achievement (Byron, 1995; House, 2006; Kayaaslan, 2006; Kloosterman \& Stage, 1992; Mason \& Scrivani, 2004; McLeod, 1992; McLeod \& McLeod, 2002; Raymond, 1997; Sağlam \& Dost, 2014; Schoenfeld, 1989). For this reason, it can be said that the experiences of mathematics and mathematical problem solving at the primary school level are a fundamental factor affecting future learning processes. Establishing an accurate and effective mathematical foundation is thought to be related to the teacher's structuring the teaching process in a way to develop positive beliefs.

The teachers' beliefs about mathematics and problem solving can affect the teaching processes and also students' beliefs. They manage the process in teaching activities mostly influenced by their own experiences (Raymond, 1997). Their beliefs are effective in the decisions they make about the difficulties they encounter during the teaching phase (Abrosse et al. 2004). With these effects beliefs are created in the process, the teachers' beliefs lead to the formation of students' beliefs (Baydar \& Bulut, 2002; Sağlam and Dost, 2014; Wilkins \& Brand, 2004). In addition, pre-service teachers' beliefs about mathematical problem solving were determined to be an effective factor in the structuring of learningteaching processes in the future and success of their students (Frykholm, 2003; Kayan \& Çakıroğlu, 2008; Lloyd \& Wilson, 1998). Therefore, as the teacher of the future, pre-service teachers' beliefs about mathematical problem solving are among the important research topics. In addition, one of the effective factors in problem solving is the metacognitive needs (Lin, Schwartz \& Hatano 2005). In addition, there is a positive and significant relationship between beliefs and attitudes towards problem solving and metacognitive 
awareness (Baş, Özturan-Sağırlı \& Bekdemir, 2016). For this reason, metacognitive awareness, which is another factor taken as the basis in problem solving, is explained.

\section{Metacognitive awareness}

Metacognition brought to the literature by John Flavell can be expressed as the knowledge of cognition in its widest sense. While cognition includes the mental activities performed by the individual in perceiving, remembering and thinking (Cüceloğlu, 2012), metacognitive is defined as the individual's being aware of his/her way of thinking, strengths and weaknesses while guiding the learning process (Çeliköz et al. 2012). Metacognition is necessary for successful learning because cognition is about performing a task and metacognition is about understanding how to perform a task (Schraw, 1998). For example, a student may have full knowledge of mathematical operations, but if he/she does not know how to use these operations in the process of solving a problem, he/she will not succeed in problem solving.

Metacognitive teaching is a process that teachers should follow while planning learning processes. Students should be taught how to use their knowledge and skills for a learning task in order to prevent the stagnation of their learning skill (Akın \& Abacl, 2011). It includes structuring learners based on the teaching of metacognitive strategies that will provide information and control over their learning processes. While cognitive teaching focuses on the inculcation of special skills in planning instructional situations, metacognitive teaching focuses on controlling the process (Baker \& Brown, 1980). Metacognition consists of two components: metacognitive knowledge and metacognitive control. Metacognitive knowledge is the individual's knowledge what skills, resources and tactics the task to be performed requires. Metacognitive control is the individual's knowing when and how to use these skills, resources and tactics in order to successfully complete the task (Schunk, 2009). Therefore, in the metacognitive teaching process, students are asked to perform some metacognitive skills such as task analysis, planning, monitoring, control or evaluation, summarizing and interpretation. Thus, this process supports the development of metacognitive thinking skills. Metacognitive thinking involves the learner's evaluation of his/her actions towards the learning process (Flavell, 1979; Reeve \& Brown, $\underline{1985}$; Wilson \& Bai, 2010). Students should be made aware of these skills and to construct their learning processes.

The knowledge an individual has about metacognitive skills refers to the metacognitive awareness. In other words, metacognitive awareness can be defined as the act of acquiring and using the metacognitive thinking skills that an individual will need throughout his/her life (Demirsöz, 2014). Low metacognitive knowledge and skills are factors affecting children's problem solving behaviors (Gelbal, 1991). It has been determined in various research studies that metacognition contributes to learners' mathematical problem solving achievement (Davis, 1984; Desoete, Roeyers \& Buysse, 2001; Kapa, 2001; Kramarski, Mevarech \& Arami, 2002; Krulik ve Rudnick, 1996; Polya, 1957; Schoenfeld, 1985; Stillman \& Galbraith, 1998; Stylianou, 2000). For this reason, students with high metacognitive awareness will be individuals who have developed other skills such as problem solving targeted by each education system and have learned how to learn. Teachers can be a model for students in the development of metacognitive skills (Öztürk \& Serin, 2020). The important point here is that teachers' expressions and behaviors towards their metacognitive awareness are clearly noticed, modelled and internalized by students (Schunk, 1989). Therefore, it can be said that students' metacognitive awareness is an important factor to be examined, and having high metacognitive awareness will increase their beliefs about solving both social and mathematical problems. 
In brief, metacognitive awareness is a variable that is thought to affect beliefs about problem solving. In addition, gender can be regarded among the important variables in educational research (Duatepe-Paksu, 2008). However, when the literature is examined, it is seen that the research studies mostly focus on the relationship between metacognitive awareness and problem solving skills. In addition, researches conducted with pre-service primary school teachers are limited. The foundations for the development of belief in mathematical problem solving and metacognitive awareness are laid at the primary school level. It is the primary school teachers who will provide this in primary school. For this reason, it is important to reveal the beliefs and metacognitive awareness of pre-service primary school teachers towards mathematical problem solving and prepare educational processes for the needs in line with the results obtained and to realize future goals. It is thought that the results will contribute to the research studies that will be carried out regarding the investigation of the relationship between metacognitive awareness and beliefs about problem solving, and its implementation with pre-service primary school teachers. Accordingly, the purpose of the current study is to determine pre-service primary school teachers' metacognitive awareness and beliefs about mathematical problem solving. In this regard, the sub-problems addressed in the current study are given below.

1. What is the level of pre-service primary school teachers' metacognitive awareness and beliefs about mathematical problem solving?

2. Do pre-service primary school teachers' metacognitive awareness and beliefs about mathematical problem solving vary significantly depending on gender?

3. Does pre-service primary school teachers' metacognitive awareness predict their beliefs about mathematical problem solving?

\section{Research Methods}

The present study aims to investigate pre-service primary school teachers' metacognitive awareness and beliefs about mathematical problem solving by employing the correlational survey model, one of the quantitative research methods. Correlational survey is a research model that aims to reveal the existence and degree of covariance between two or more variables (Karasar, 2014). In this regard, it is aimed to investigate pre-service primary school teachers' metacognitive awareness and beliefs about mathematical problem solving according to different variables and to discuss the findings to be obtained in light of the relationships to emerge between metacognitive awareness and beliefs about mathematical problem solving.

\section{Participants}

The participants of the current research comprise of 284 pre-service primary school teachers attending at the Department of Primary Education in an education faculty of a state university in the Aegean Region in the spring term of the 2016-2017 academic year. The demographic features of the participants are given in Table 1. As can be seen in Table 1, $193(68 \%)$ of the participating 284 pre-service teachers are females and $91(32 \%)$ are males. Of the participating pre-service teachers, $80(28.2 \%)$ are first-year students, 70 (24.6\%) are second-year students, 75 (26.4\%) are third-year students, and 59 (20.8\%) are fourth-year students. When the grade point averages of the pre-service teachers are examined, it is seen that $25(8.8 \%)$ of them are in the range of " 2.00 and lower", 182 $(64.1 \%)$ of them have a grade point average in the range of "between 2.01 and 3.00" and 77 $(27.1 \%)$ of them are in the range of " 3.01 and higher". 
Table 1

Demographic features of the participants

\begin{tabular}{llcc}
\hline Demographic features & & $\mathrm{f}$ & $\%$ \\
\hline \multirow{2}{*}{ Gender } & Female & 193 & 68 \\
& Male & 91 & 32 \\
\multirow{3}{*}{ Grade Level } & First year & 80 & 28.2 \\
& Second year & 70 & 24.6 \\
& Third year & 75 & 26.4 \\
\multirow{4}{*}{ Grade Point Average } & Fourth year & 59 & 20.8 \\
& 2.00 and lower & 25 & 8.8 \\
& Between 2.01 and 3.00 & 182 & 64.1 \\
& 3.01 and higher & 77 & 27.1 \\
\hline
\end{tabular}

\section{Instruments}

In the data collection, the "Metacognitive Awareness Inventory" developed by Schraw and Dennison (1994) and adapted to Turkish by Akın, Abacı and Çetin (2007) was used. When it comes to the "Scale of Beliefs about Mathematical Problem Solving", it was developed by Kloosterman and Stage (1992) and adapted to Turkish by Haciömeroğlu (2011a) was employed. Information about the pre-service teachers' gender, grade level and grade point average was collected with a personal information form.

The Metacognitive Awareness Inventory was employed to determine university students' metacognitive awareness. The inventory comprises of 52 items to be responded on a 5-point Likert scale: "Never", "Rarely", "Frequently", "Generally" and "Always". The highest score to be taken from the inventory is 260 while the lowest score is 52 . The scale consists of two main dimensions, called knowledge of cognition and regulation of cognition and eight sub-dimensions subsumed under these two main dimensions. The dimension of knowledge of cognition includes the following sub-dimensions: declarative knowledge, procedural knowledge and conditional knowledge. The dimension of regulation of knowledge includes the following sub-dimensions: planning, monitoring, evaluation of learning, debugging strategies and information management strategies. There is no reverse-coded item in the inventory. The internal consistency reliability coefficient was found to be .95 . As a result of the analysis conducted in this research study, the internal consistency coefficient for the whole inventory was found to be .96 .

The Scale of Beliefs about Mathematical Problem Solving was employed to measure pre-service teachers' beliefs about mathematical problem solving. The scale consists of 25 five-point Likert scale items and 5 sub-dimensions. The sub-dimensions of the scale are mathematical ability, place of mathematics, understanding the problem, importance of mathematics and problem solving skill. There are 7 reverse-coded items in the scale. While analyzing these reverse-coded items, the scoring is also reversed. The lowest score to be taken from the scale is 24 while the highest score is 120 . In the adaptation study of the scale, the internal consistency reliability coefficient was calculated to be .77. As a result of the analysis conducted in the current study, the internal consistency reliability coefficient of the scale was found to be .80 .

\section{Data collection}

The necessary permissions were obtained from the institution in order to collect the data of the study from the students studying at the Faculty of Education of a state university in the Aegean Region in the spring term of the 2016-2017 academic year. After the required permissions had been taken to administer the measurement tools in the predetermined classes for each grade level, the students were informed about the study. The 
participation in the study was on a voluntary basis. The participating students were given the questionnaire consisting of the measurement tools and personal information form and they were given adequate time to complete the questionnaire. It took 30-35 minutes for the participants to complete the questionnaire and then the data collection process was ended.

\section{Data analysis}

In the analysis of the collected data, a statistical program was used. In the analysis phase, descriptive statistics and inferential statistics were used. Through descriptive statistics, the participating students' level of metacognitive awareness and beliefs about mathematical problem solving were attempted to be revealed. Through inferential statistics, the between-groups correlations were attempted to be revealed.

Before starting the analysis of the data in the study, normality analyses were made to check whether the data were normally distributed. The Normal Q-Q Plot Graph regarding the normality of the scores obtained from the Metacognitive Awareness Inventory and the Scale of Beliefs about Mathematical Problem Solving is given in Figure 1 and Figure 2.

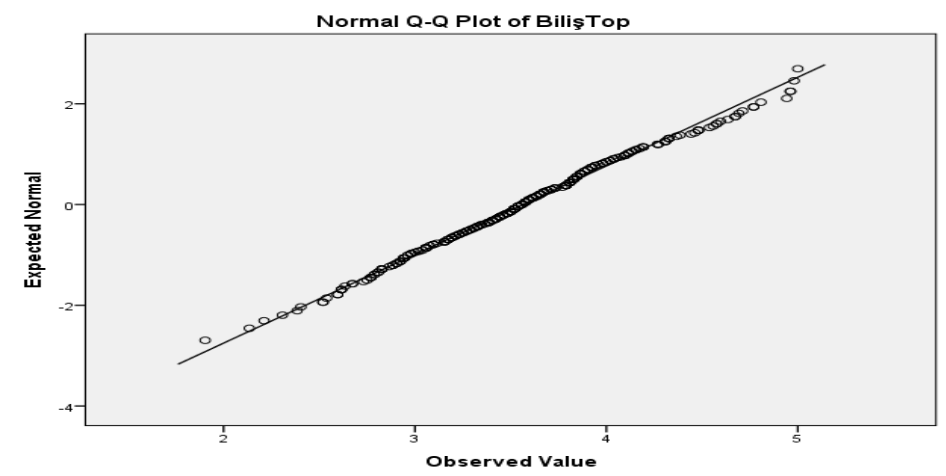

Figure 1. Normal Q-Q plot graph for the Metacognitive Awareness Inventory

When Figure 1 is examined, the data are collected around the line standing at an angle of 45 degrees. This indicates that the scores obtained from the Metacognitive Awareness Inventory showed a normal distribution.

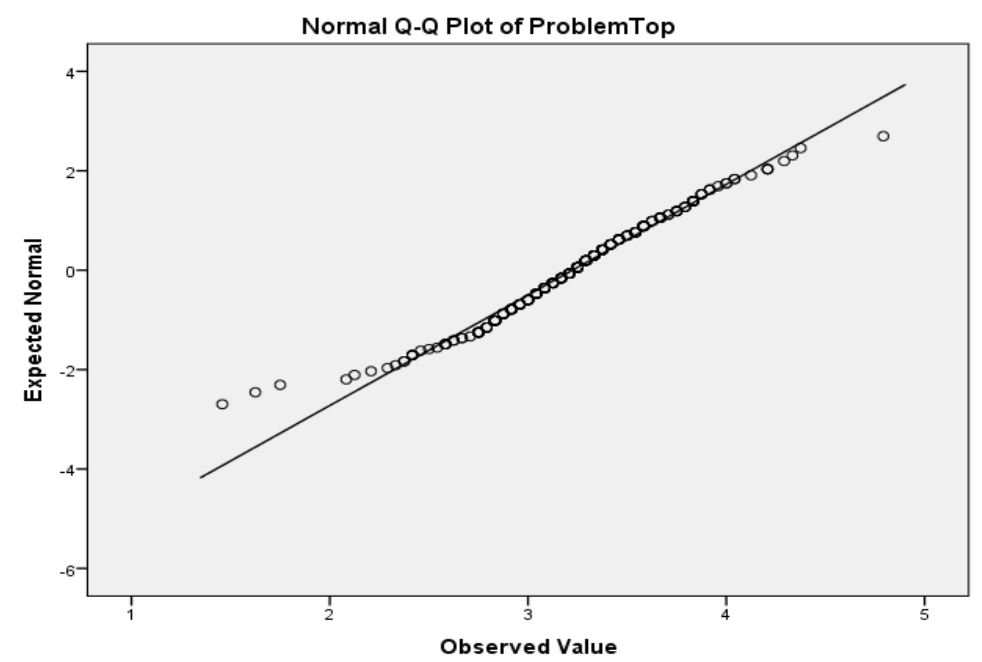

Figure 2. Normal Q-Q plot graph for the Scale of Beliefs about Mathematical Problem Solving

When Figure 2 is examined, the data are collected around the line standing at an angle of 45 degrees. This indicates that the scores obtained from the Scale of Beliefs about Mathematical Problem Solving showed a normal distribution. 
As a result of the analyses, it was decided that the data set would be suitable for parametric analysis. T-test was used to determine whether the scores taken from the scales vary significantly depending on gender. The obtained results were interpreted at the .05 significance level. Pearson Product-Moment Correlation analysis was conducted to determine whether there is a correlation between the participants' metacognitive awareness and beliefs about mathematical problem solving and to determine the direction of the correlation (if there is any). When the correlation coefficient is .30 or lower, it indicates a "low" correlation; when it is between .30 and .70, then it indicates a "medium" correlation and when it is .70 or higher, then it indicates a "high" correlation (Büyüköztürk, 2012). Finally, simple linear regression analysis was employed to determine the extent to which the pre-service teachers' metacognitive awareness predicts their beliefs about mathematical problem solving.

The score obtained by dividing the score obtained from the inventory by the total number of items gives the metacognitive awareness level of the respondent. When this score is lower than 2.5, it means the metacognitive awareness is "low" but when it is higher than 2.5, then it means the metacognitive awareness is "high" (Akın et al. 2007). On the other hand, when the score taken from the Scale of Beliefs about Mathematical Problem Solving is between 0 and 1.67, then it means a "low" general belief, when it is between 1.68 and 3.36, then it means a "medium" general belief and when it is between 3.37 and 5.00, then it means a "high" general belief.

\section{Results and Discussion}

Research Question 1: What is the level of pre-service primary school teachers' metacognitive awareness and beliefs about mathematical problem solving?

Means, standard deviations, minimum and maximum values and levels regarding the pre-service teachers' metacognitive awareness and beliefs about mathematical problem solving are calculated. They are given in Table 2 and Table 3.

Table 2

Descriptive statistics regarding the Metacognitive Awareness Inventory

\begin{tabular}{cccccccc}
\hline \multirow{2}{*}{ Main Dimensions } & Sub-dimensions & $\mathrm{N}$ & $\overline{\mathrm{x}}$ & $\mathrm{sd}$ & $\begin{array}{c}\text { Min. } \\
\text { Value }\end{array}$ & $\begin{array}{c}\text { Max. } \\
\text { Value }\end{array}$ & $\begin{array}{c}\text { Level } \\
\end{array}$ \\
& Declarative knowledge & 284 & 3.63 & .62 & 1.50 & 5.00 & High \\
& Procedural knowledge & 284 & 3.52 & .68 & 1.50 & 5.00 & High \\
Knowledge of cognition & Conditional knowledge & 284 & 3.65 & .65 & 1.80 & 5.00 & High \\
& & 284 & 3.60 & .60 & 1.95 & 5.00 & High \\
Knowledge of cognition & Planning & 284 & 3.58 & .63 & 2.29 & 5.00 & High \\
& Monitoring & 284 & 3.49 & .63 & 2.00 & 5.00 & High \\
& Evaluation & 284 & 3.50 & .67 & 1.67 & 5.00 & High \\
Regulation of cognition & Debugging & 284 & 3.57 & .68 & 1.40 & 5.00 & High \\
& Information management & 284 & 3.57 & .62 & 1.44 & 5.00 & High \\
Regulation of cognition & & 284 & 3.54 & .58 & 1.90 & 5.00 & High \\
Metacognitive awareness & & 284 & 3.56 & .57 & 1.90 & 5.00 & High \\
\hline
\end{tabular}

When Table 2 showing the descriptive statistics regarding the metacognitive awareness of the 284 pre-service primary school teachers is examined, it is seen that the pre-service teachers' mean metacognitive awareness score $(\bar{X}=3.56)$ is high. The mean scores taken from the main dimensions of the inventory $(\bar{X}=3.60$ for the knowledge of cognition and $\bar{X}=3.54$ for the regulation of cognition) were found to be high as well. 
Moreover, it can be said that the mean scores the pre-service primary school teachers got from the sub-dimensions are also high.

As a result of the current study, the pre-service primary school teachers' metacognitive awareness was found to be high. This result concurs with the existing research on pre-service primary school teachers' metacognitive awareness (Baysal, Ayvaz, Çekirdekçi \& Malbeleği, 2013; Erbaş Karaduman \& Yavuz, 2018; Memnun \& Akkaya. 2012). Öztürk and Serin (2020) also found that the pre-service primary school teachers have metacognitive awareness over the average. Moreover, in other studies including preservice teachers from other branches as well as pre-service primary school teachers, it was found that the metacognitive awareness of the pre-service primary school teachers is higher than the metacognitive awareness of pre-service teachers from other branches (Özturan-Sağırlı, Baş and Bekdemir, 2020). Metacognitive awareness was also found to be high in studies conducted on pre-service teachers although not specific result was reported on pre-service primary school teachers (Baş, Özturan-Sağırlı \& Bekdemir, 2016). A high level of metacognitive awareness is an indication that pre-service primary school teachers have the ability to control learning processes, and it can be described as a desirable situation. The reason why pre-service teachers' metacognitive awareness was determined to be high in the existing research may be that they discovered their own learning processes because the lessons they took during their education were learning-teachingfocused.

Table 3

Descriptive Statistics regarding the Scale of Beliefs about Mathematical Problem Solving

\begin{tabular}{llccccc}
\hline Sub-dimensions & \multirow{2}{*}{$\overline{\mathrm{N}}$} & $\mathrm{sd}$ & $\begin{array}{l}\text { Min. } \\
\text { Value }\end{array}$ & $\begin{array}{l}\text { Max. } \\
\text { Value }\end{array}$ & Level \\
\hline Mathematical ability & 284 & 3.76 & .89 & 1.00 & 5.00 & High \\
Place of mathematics & 284 & 2.24 & .94 & 1.00 & 5.00 & Medium \\
Understanding the problem & 284 & 3.47 & .78 & 1.00 & 5.00 & High \\
Importance of mathematics & 284 & 3.60 & .83 & 1.00 & 5.00 & High \\
Problem solving skill & 284 & 3.31 & .75 & 1.00 & 5.00 & Medium \\
Beliefs about mathematical problem solving & 284 & 3.22 & .45 & 1.49 & 5.00 & Medium \\
\hline
\end{tabular}

When Table 3 is examined, it is seen that the pre-service teachers' mean score $(\overline{\mathrm{X}}=3.22)$ taken from the Scale of Beliefs about Mathematical Problem Solving is medium. When the mean scores taken from the sub-dimensions of the scale are examined, it is seen that the mean scores taken from the sub-dimensions of mathematical ability $(\overline{\mathrm{X}}=3.76)$, understanding the problem $(\overline{\mathrm{X}}=3.47)$ and importance of mathematics $(\overline{\mathrm{X}}=3.60)$ are high. Moreover, the mean scores taken from the sub-dimensions of place of mathematics $(\overline{\mathrm{X}}=2.24)$ and understanding the problem $(\overline{\mathrm{X}}=3.31)$ are medium.

In the current study, the pre-service primary school teachers' beliefs about mathematical problem solving were found to be medium. The results were supported by the studies conducted on pre-service primary school teachers by Deringöl ( $\underline{2018})$, Toptaş

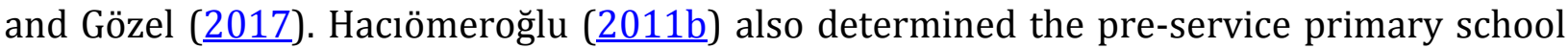
teachers' beliefs about mathematical problem solving at the level of "Agree" for the subdimensions of mathematical ability, understanding the problem and importance of mathematics; at the level of "Disagree" for the sub-dimension of place of mathematics and at the level of "Undecided" for the sub-dimension of problem solving skill. In the studies carried out with the participation of pre-service math teachers, beliefs about mathematical problem solving were found to be positive and high (Gülten \& Soytürk, 2012; Kayan \& Çakıroğlu, 2008; Ünlü \& Sarpkaya-Aktaș, 2016; Yavuz \& Erbay, 2015). The fact that pre- 
service primary school teachers generally graduate from departments of high schools where Turkish-centred courses are emphasized as much as math-centred courses can be the reason why their beliefs about mathematical problem solving are medium. It can also be stated that the level of belief in problem solving is medium indicates that the pre-service primary school teachers are in a situation that can be developed towards understanding and solving the problem.

Research Question 2: Do pre-service primary school teachers' metacognitive awareness and beliefs about mathematical problem solving vary significantly depending on gender?

The results of the t-test conducted to determine whether the pre-service primary school teachers' metacognitive awareness varies significantly depending on grade level are given in Table 4.

Table 4

Results of the T-test conducted to determine whether the pre-service primary school Teachers' Metacognitive Awareness varies significantly depending on gender

\begin{tabular}{|c|c|c|c|c|c|c|c|c|}
\hline Main dimensions & Sub-dimensions & & $\mathrm{N}$ & $\bar{X}$ & $\mathrm{~S}$ & $\mathrm{Sd}$ & $\mathrm{t}$ & $\mathrm{p}$ \\
\hline \multirow{6}{*}{$\begin{array}{l}\text { Knowledge of } \\
\text { cognition }\end{array}$} & \multirow{2}{*}{ Declarative knowledge } & Female & 193 & 3.60 & .61 & \multirow{2}{*}{282} & \multirow{2}{*}{-1.40} & \multirow{2}{*}{.16} \\
\hline & & Male & 91 & 3.71 & .64 & & & \\
\hline & \multirow{2}{*}{ Procedural knowledge } & Female & 193 & 3.51 & .67 & \multirow{2}{*}{282} & \multirow{2}{*}{-.26} & \multirow{2}{*}{.79} \\
\hline & & Male & 91 & 3.54 & .70 & & & \\
\hline & \multirow{2}{*}{ Conditional knowledge } & Female & 193 & 3.64 & .62 & \multirow{2}{*}{282} & \multirow{2}{*}{-.07} & \multirow{2}{*}{.94} \\
\hline & & Male & 91 & 3.65 & .70 & & & \\
\hline \multirow{6}{*}{$\begin{array}{l}\text { Knowledge of } \\
\text { cognition }\end{array}$} & & Female & 193 & 3.58 & .59 & \multirow{2}{*}{282} & \multirow{2}{*}{-.61} & \multirow{2}{*}{.54} \\
\hline & & Male & 91 & 3.63 & 63 & & & \\
\hline & \multirow{2}{*}{ Planning } & Female & 193 & 3.54 & .61 & \multirow{2}{*}{282} & \multirow{2}{*}{-1.36} & \multirow{2}{*}{.17} \\
\hline & & Male & 91 & 3.65 & .67 & & & \\
\hline & \multirow{2}{*}{ Monitoring } & Female & 193 & 3.45 & .62 & \multirow{2}{*}{282} & \multirow{2}{*}{-1.34} & \multirow{2}{*}{.18} \\
\hline & & Male & 91 & 3.56 & .65 & & & \\
\hline \multirow{6}{*}{$\begin{array}{l}\text { Regulation of } \\
\text { knowledge }\end{array}$} & \multirow{2}{*}{ Evaluation } & Female & 193 & 3.49 & .67 & \multirow{2}{*}{282} & \multirow{2}{*}{-.24} & \multirow{2}{*}{.81} \\
\hline & & Male & 91 & 3.51 & .67 & & & \\
\hline & \multirow{2}{*}{ Debugging } & Female & 193 & 3.58 & .67 & \multirow{2}{*}{282} & \multirow{2}{*}{.38} & 71 \\
\hline & & Male & 91 & 3.55 & .71 & & & \\
\hline & & Female & 193 & 3.54 & .61 & 282 & -134 & \\
\hline & Information management & Male & 91 & 3.65 & .64 & 282 & -1.34 & .18 \\
\hline Regulation of & & Female & 193 & 3.52 & .57 & 202 & 81 & 10 \\
\hline knowledge & & Male & 91 & 3.58 & 60 & 282 & -.04 & .40 \\
\hline Metacognitive & & Female & 193 & 3.54 & .56 & 282 & -94 & 35 \\
\hline awareness & & Male & 91 & 3.61 & .59 & 202 & .04 & J \\
\hline
\end{tabular}

In Table 4, it is seen that the pre-service teachers' metacognitive awareness does not vary significantly depending on gender $\left(\mathrm{t}_{(282)}=-.94 ; \mathrm{p}>.05\right)$. However, the male pre-service teachers' mean metacognitive awareness score $(\overline{\mathrm{X}}=3.61)$ was found to be higher than that of the female pre-service teachers $(\bar{X}=3.54)$. When the mean scores taken from the main dimensions of the scale were examined, it was found that the mean scores of knowledge of cognition do not vary significantly but the male pre-service teachers $\left(\mathrm{t}_{(284)}=-.61 ; \mathrm{p}>.05\right)$ is higher than that of the female pre-service teachers $(\bar{X}=3.63)$. Similarly, the mean scores taken from the dimension of regulation of knowledge were also found to be not varying significantly depending on gender $\left(\mathrm{t}_{(282)}=-.84 ; \mathrm{p}>.05\right)$. However, the mean score of the male pre-service teachers $(\overline{\mathrm{X}}=3.58)$ was found to be higher than that of the female pre- 
service teachers $(\overline{\mathrm{X}}=3.52)$. When the scores taken from the sub-dimensions of the main dimension of knowledge of condition were examined, the mean scores of declarative knowledge $\left(\mathrm{t}_{(284)}=-1.40 ; \mathrm{p}>.05\right)$, procedural knowledge $\left(\mathrm{t}_{(282)}=-.26 ; \mathrm{p}>.05\right)$ and conditional knowledge $\left(\mathrm{t}_{(284)}=-.07 ; \mathrm{p}>.05\right)$ were found to be not varying significantly depending on gender. For these three sub-dimensions, the mean scores of the male preservice teachers $\left(\overline{\mathrm{X}}_{\text {declerativeknowledge }}=3.71 ; \overline{\mathrm{X}}_{\text {proceduralknowledge }}=3.54 ; \overline{\mathrm{X}}_{\text {conditionalknowledge }}=3.65\right)$ were found to be higher than those of the female pre-service teachers $\left(\overline{\mathrm{X}}_{\text {declarativeknowledge }}=\right.$ $3.60 ; \overline{\mathrm{X}}_{\text {proceduralknowledge }}=3.51 ; \overline{\mathrm{X}}_{\text {conditionalknowledge }}=3.64$ ). When the scores taken from the subdimensions of the main dimension of regulation of knowledge were examined, it was found that the mean scores taken from the sub-dimensions of planning $\left(\mathrm{t}_{(282)}=-1.36 ; \mathrm{p}>.05\right)$, monitoring $\left(\mathrm{t}_{(282)}=-1.34 ; \mathrm{p}>.05\right)$, evaluation $\left(\mathrm{t}_{(282)}=-.24 ; \mathrm{p}>.05\right)$ debugging $\left(\mathrm{t}_{(282)}=-.38\right.$; $\mathrm{p}>.05)$ and information management $\left(\mathrm{t}_{(282)}=-1.34 ; \mathrm{p}>.05\right)$ do not vary significantly depending on gender. The mean scores taken from these four sub-dimensions by the male pre-service teachers $\left(\overline{\mathrm{X}}_{\text {planning }}=3.65 ; \overline{\mathrm{X}}_{\text {monitoring }}=3.56 ; \overline{\mathrm{X}}_{\text {evaluation }}=3.51 ; \overline{\mathrm{X}}_{\text {information management }}=\right.$ 3.65) were found to be higher than those of the female pre-service teachers $\left(\bar{X}_{\text {planning }}=3.54\right.$; $\left.\overline{\mathrm{X}}_{\text {monitoring }}=3.45 ; \overline{\mathrm{X}}_{\text {evaluation }}=3.49 ; \overline{\mathrm{X}}_{\text {information management }}=3.54\right)$. On the other hand, the mean score taken by the female pre-service teachers from the sub-dimension of debugging $(\bar{X}=$ 3.58) was found to be higher than that of the male teachers $(\bar{X}=3.55)$.

The pre-service primary school teachers' metacognitive awareness was found to be not varying significantly depending on gender in the current study. Tunçer (2013) also concluded in the research study on pre-service primary school teachers that the preservice primary school teachers' metacognitive awareness does not vary significantly depending on gender. Moreover, Dilci and Kaya (2012) reported a similar finding in their study on pre-service primary school teachers. It was also found that gender is not a factor influential on metacognitive awareness in the studies conducted by Kişkır (2011) on preservice teachers, by Özsoy and Günindi (2011) on pre-service primary school teachers, by Deniz, Küçük, Cansız, Akgün and İşleyen (2014) on pre-service math teachers, by Gül, Köse and Yllmaz ( $\underline{2015})$ on pre-service biology teachers. On the other hand, there are also studies reporting gender-based significant differences in pre-service teachers' metacognitive awareness levels (Belet \& Güven, 2011; Baykara. 2011; Kana, 2015; Öztürk \& Serin, 2020). In light of this result, it can be said that pre-service teachers' gender is not a factor influential on the formation of metacognition and awareness of this, and that metacognition can develop at the same level in all pre-service teachers regardless of their gender.

The results of the t-test conducted to determine whether the pre-service primary school teachers' beliefs about mathematical problem solving vary significantly depending on gender are given in Table 5. To determine whether the pre-service primary school teachers' beliefs about mathematical problem solving vary significantly depending on gender, independent samples t-test was employed. When the Table 5 are examined, it is seen that the pre-service teachers' beliefs about mathematical problem solving vary significantly depending on gender $\left(\mathrm{t}_{(282)}=-3.25 ; \mathrm{p}<.05\right)$. The mean score of the male preservice teachers $(\bar{X}=3.35)$ was found to be significantly higher than that of the female preservice teachers $(\overline{\mathrm{X}}=3.17)$.

It was also investigated whether the mean scores taken from the sub-dimensions of the scale vary significantly depending on gender. It was found that the mean scores taken from the sub-dimensions of mathematical ability $\left(\mathrm{t}_{(282)}=-1.65 ; \mathrm{p}>.05\right)$, place of mathematics $\left(\mathrm{t}_{(282)}=-1.05 ; \mathrm{p}>.05\right)$ and understanding the problem $\left(\mathrm{t}_{(282)}=-1.69 ; \mathrm{p}>.05\right)$ do not vary significantly depending on gender. On the other hand, the mean scores taken from the sub-dimension of importance of mathematics were found to be varying significantly 
depending on gender $\left(\mathrm{t}_{(282)}=-2.35 ; \mathrm{p}<.05\right)$. The mean score of the male pre-service teachers $(\overline{\mathrm{X}}=3.76)$ was found to be significantly higher than that of the female pre-service teachers $(\overline{\mathrm{X}}=3.52)$. The mean scores taken from the sub-dimension of problem solving skill were found to be varying significantly depending on gender $\left(\mathrm{t}_{(282)}=-2.51 ; \mathrm{p}<.05\right)$. The mean score of the male pre-service teachers $(\overline{\mathrm{X}}=3.35)$ was found to be significantly higher than that of the female pre-service teachers $(\overline{\mathrm{X}}=3.17)$.

Table 5

Results of the T-test conducted to determine whether the pre-service primary school Teachers' Beliefs about Mathematical Problem Solving vary significantly depending on gender

\begin{tabular}{|c|c|c|c|c|c|c|c|}
\hline & & $\mathrm{N}$ & $\bar{X}$ & $S$ & Sd & $\mathrm{t}$ & $\mathrm{p}$ \\
\hline \multirow{2}{*}{ Mathematical ability } & Female & 193 & 3.70 & .82 & \multirow{2}{*}{282} & \multirow{2}{*}{-1.65} & \multirow{2}{*}{.10} \\
\hline & Male & 91 & 3.88 & 1.02 & & & \\
\hline \multirow{2}{*}{ Place of mathematics } & Female & 193 & 2.20 & .89 & \multirow{2}{*}{282} & \multirow{2}{*}{-1.05} & \multirow{2}{*}{.30} \\
\hline & Male & 91 & 2.32 & 1.04 & & & \\
\hline \multirow{2}{*}{ Understanding the problem } & Female & 193 & 3.42 & .69 & \multirow{2}{*}{282} & \multirow{2}{*}{-1.69} & \multirow{2}{*}{.09} \\
\hline & Male & 91 & 3.59 & .92 & & & \\
\hline \multirow{2}{*}{ Importance of mathematics } & Female & 193 & 3.52 & .82 & \multirow{2}{*}{282} & \multirow{2}{*}{-2.35} & \multirow{2}{*}{.02} \\
\hline & Male & 91 & 3.76 & .34 & & & \\
\hline \multirow{2}{*}{ Problem solving skill } & Female & 193 & 3.23 & .72 & \multirow{2}{*}{282} & \multirow{2}{*}{-2.51} & \multirow{2}{*}{.01} \\
\hline & Male & 91 & 3.47 & .80 & & & \\
\hline \multirow{2}{*}{$\begin{array}{l}\text { Beliefs about } \\
\text { problem solving }\end{array}$} & Female & 193 & 3.17 & .40 & \multirow{2}{*}{282} & \multirow{2}{*}{-3.25} & \multirow{2}{*}{.00} \\
\hline & Male & 91 & 3.35 & .53 & & & \\
\hline
\end{tabular}

In the study, the pre-service primary school teachers' beliefs about mathematical problem solving were found to be varying significantly by gender in favor of the male preservice teachers. The reason why the male pre-service teachers got significantly higher scores for beliefs about mathematical problem solving than the female pre-service teachers may be that they encounter more problem situations in the society. Soytürk (2011) also found that the pre-service primary school teachers' beliefs about mathematical problem solving vary significantly by gender but in favor of the female pre-service teachers. In other similar studies conducted on pre-service primary school teachers, the gender variable was found to have no significant effect on beliefs about mathematical problem solving (Toptaş and Gözel, 2017). In studies conducted on pre-service math teachers, the results obtained about the effect of the gender variable are not similar to the result of the present study (Baş et al. 2016; Gülten \& Soytürk, 2012; Kayan \& Çakıroğlu, 2008; Sağlam \& Dost, 2014; Yavuz \& Erbay, 2015).

Research Question 3: Does pre-service primary school teachers' metacognitive awareness predict their beliefs about mathematical problem solving?

The results of the Pearson Product-Moment Correlation analysis conducted to determine the relationship between the pre-service primary school teachers' metacognitive awareness and beliefs about mathematical problem solving are presented in Table 6. To determine whether there is a correlation between the pre-service primary school teachers' metacognitive awareness and beliefs about mathematical problem solving or not, simple linear correlation analysis was conducted. The results have revealed that there is a positive and medium correlation between their metacognitive awareness and beliefs about mathematical problem solving $(\mathrm{r}=.35 ; \mathrm{p}<.01)$. 


\section{Table 6}

Results of the Pearson product-moment correlation analysis conducted to determine the relationship between Metacognitive Awareness and Beliefs about Mathematical Problem Solving

\begin{tabular}{|c|c|c|c|c|c|c|c|c|c|c|c|c|c|c|c|}
\hline & 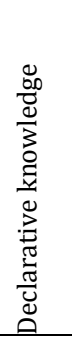 & 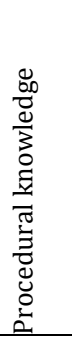 & 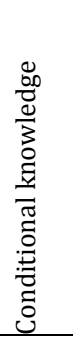 & $\stackrel{\infty}{\stackrel{a}{\Xi}}$ & 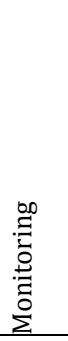 & 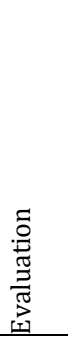 & 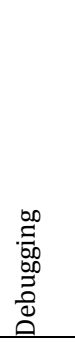 & 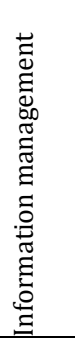 & 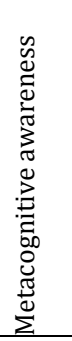 & 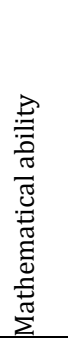 & 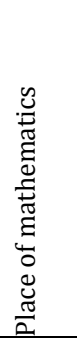 & 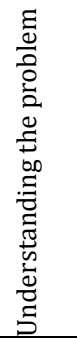 & 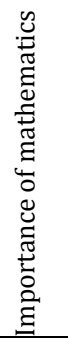 & 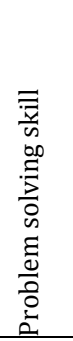 & 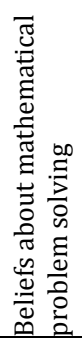 \\
\hline $\begin{array}{l}\text { Declarative } \\
\text { knowledge }\end{array}$ & 1,00 & & & & & & & & & & & & & & \\
\hline $\begin{array}{l}\text { Procedural } \\
\text { knowledge }\end{array}$ &, $77^{* *}$ & 1,00 & & & & & & & & & & & & & \\
\hline $\begin{array}{l}\text { Conditional } \\
\text { knowledge }\end{array}$ &, $79^{* *}$ &, $77^{* *}$ & 1,00 & & & & & & & & & & & & \\
\hline Planning &, $76^{* *}$ &, $74^{* *}$ &, $72^{* *}$ & 1,00 & & & & & & & & & & & \\
\hline Monitoring &, $75^{* *}$ &, $75^{* *}$ &, $74^{* *}$ & $81^{* *}$ & 1,00 & & & & & & & & & & \\
\hline Evaluation &, $78^{* *}$ &, $75^{* *}$ &, $76^{* *}$ &, $77^{* *}$ & $80^{* *}$ & 1,00 & & & & & & & & & \\
\hline Debugging &, $65^{* *}$ &, $61^{* *}$ &, $63^{* *}$ &, $65^{* *}$ & $68^{* *}$ &, $70^{* *}$ & 1,00 & & & & & & & & \\
\hline $\begin{array}{l}\text { Information } \\
\text { management }\end{array}$ &, $83^{* *}$ &, $76^{* *}$ &, $75^{* *}$ &, $78^{* *}$ &, $82^{* *}$ &, $82^{* *}$ &, $71^{* *}$ & 1,00 & & & & & & & \\
\hline $\begin{array}{l}\text { Metacognitive } \\
\text { awareness }\end{array}$ &, $90^{* *}$ &, $86^{* *}$ &, $86^{* *}$ & $89^{* *}$ &, $91^{* *}$ & $91^{* *}$ &, $79^{* *}$ &, $93^{* *}$ & 1,00 & & & & & & \\
\hline $\begin{array}{l}\text { Mathematical } \\
\text { ability }\end{array}$ &, $27^{* *}$ &, $26^{* *}$ &, $31^{* *}$ &, $29^{* *}$ &, $31^{* *}$ &, $27^{* *}$ &, $19^{* *}$ & $25^{* *}$ &, $30^{* *}$ & 1,00 & & & & & \\
\hline $\begin{array}{l}\text { Place of } \\
\text { mathematics }\end{array}$ & , $26^{* *}$ & , $18^{* *}$ & , $23^{* *}$ & , $20^{* *}$ & $-15^{* *}$ & $-17^{* *}$ &,$- 14^{*}$ &,$- 13^{*}$ & , $20^{* *}$ & $-34^{* *}$ & 1,00 & & & & \\
\hline $\begin{array}{l}\text { Understanding } \\
\text { the problem }\end{array}$ &, $35^{* *}$ &, $39^{* *}$ &, $40^{* *}$ & $40^{* *}$ &, $40^{* *}$ &, $41^{* *}$ &, $28^{* *}$ &, $34^{* *}$ &, $42^{* *}$ &, $47^{* *}$ &,$- 23^{* *}$ & 1,00 & & & \\
\hline $\begin{array}{l}\text { Importance of } \\
\text { mathematics }\end{array}$ &, $37^{* *}$ &, $34^{* *}$ &, $30^{* *}$ &, $37^{* *}$ &, $38^{* *}$ &, $34^{* *}$ &, $26^{* *}$ &, $33^{* *}$ &, $39^{* *}$ &, $45^{* *}$ &,$- 31^{* *}$ &, $60^{* *}$ & 1,00 & & \\
\hline $\begin{array}{l}\text { Problem } \\
\text { solving skill }\end{array}$ &, $25^{* *}$ &, $29^{* *}$ &, $19^{* *}$ & $19^{* *}$ &, $21^{* *}$ &, $25^{* *}$ &, $20^{* *}$ &, $25^{* *}$ &, $26^{* *}$ &, $25^{* *}$ &,- 01 &, $35^{* *}$ &, $42^{* *}$ & 1,00 & \\
\hline $\begin{array}{l}\text { Beliefs about } \\
\text { mathematical } \\
\text { problem } \\
\text { solving }\end{array}$ &, $28^{* *}$ &, $34^{* *}$ &, $30^{* *}$ &, $32^{* *}$ &, $36^{* *}$ &, $34^{* *}$ &, $24^{* *}$ &, $33^{* *}$ &, $35^{* *}$ &, $66^{* *}$ &, $20^{* *}$ &, $71^{* *}$ &, $62^{* *}$ &, $62^{* *}$ & 1,00 \\
\hline
\end{tabular}

Moreover, a positive, weak and significant correlation was found between the subdimension of declarative knowledge and beliefs about mathematical problem solving $(\mathrm{r}=$ .28; $\mathrm{p}<.01$ ). A positive, medium, and significant correlation was found between the subdimension of procedural knowledge and beliefs about mathematical problem solving $(\mathrm{r}=$ .34; $\mathrm{p}<.01$ ). Moreover, a positive, medium and significant correlation was found between the sub-dimension of conditional knowledge and beliefs about mathematical problem 
solving $(\mathrm{r}=.30 ; \mathrm{p}<.01)$. A positive, medium and significant correlation was found between the sub-dimension of planning and beliefs about mathematical problem solving $(\mathrm{r}=.32$; $\mathrm{p}<.01)$. A positive, medium and significant correlation was found between the subdimension of monitoring and beliefs about mathematical problem solving $(r=.36 ; \mathrm{p}<.01)$. A positive, medium and significant correlation was found between the sub-dimension of evaluation and beliefs about mathematical problem solving $(\mathrm{r}=.34 ; \mathrm{p}<.01)$. A positive, weak and significant correlation was found between the sub-dimension of debugging and beliefs about mathematical problem solving $(\mathrm{r}=.24 ; \mathrm{p}<.01)$. A positive, medium and significant correlation was found between the sub-dimension of information management and beliefs about mathematical problem solving $(\mathrm{r}=.33$; $\mathrm{p}<.01)$.

A positive, medium and significant correlation was found between the sub-dimension of mathematical ability and metacognitive awareness $(\mathrm{r}=.30 ; \mathrm{p}<.01)$. A negative, low and significant correlation was found between the sub-dimension of place of mathematics and metacognitive awareness $(\mathrm{r}=-.20 ; \mathrm{p}<.01)$. A positive, medium and significant correlation was found between the sub-dimension of understanding the problem and metacognitive awareness $(\mathrm{r}=.42 ; \mathrm{p}<.01)$ and between the sub-dimension of importance of mathematics and metacognitive awareness $(\mathrm{r}=.39 ; \mathrm{p}<.01)$. A positive, weak and significant correlation was found between the sub-dimension of problem solving skill and metacognitive awareness $(\mathrm{r}=.26$; $\mathrm{p}<.01)$.

The results of the regression analysis conducted to determine the extent to which the pre-service teachers' metacognitive awareness predicts their beliefs about mathematical problem solving are presented in Table 7.

Table 7

Results of the regression analysis conducted to determine the extent to which Metacognitive Awareness predicts Beliefs about Mathematical Problem Solving

\begin{tabular}{llllllll}
\hline Variable & $\mathrm{B}$ & $\begin{array}{l}\text { Standard } \\
\text { Error }\end{array}$ & $\beta$ & $\mathrm{t}$ & $\mathrm{p}$ & $\mathrm{R}^{2}$ & $\mathrm{~F}$ \\
\hline Constant & 2.23 & .16 & - & 14.00 & .00 & .13 & 40.47 \\
Metacognitive awareness & .28 & .044 & .35 & 6.36 & .00 & & \\
\hline
\end{tabular}

$$
\mathrm{R}=.35 ; \mathrm{R}^{2}=.13 ; \mathrm{F}_{(1-282)}=40.47 ; \mathrm{p}=.00
$$

As can be seen in Table 7, according to the results of the regression analysis, the extent to which the independent variable-metacognitive awareness- predicts the dependent variable-mathematical problem solving- is statistically significant $[\mathrm{R}=.35$; $\left.\mathrm{R}^{2}=.13 ; \mathrm{F}_{(1.282)}=40.47 . \mathrm{p}<.05\right]$. The metacognitive awareness independent variable was found to explain $13 \%$ of the total variance in the variable of beliefs about mathematical problem solving. The obtained $\mathrm{F}_{(1.282)}=40.47$ value shows that the pre-service primary school teachers' level of metacognitive awareness significantly predicts beliefs about mathematical problem solving.

It was found that there is a positive, medium and significant correlation between the pre-service primary school teachers' metacognitive awareness and beliefs about mathematical problem solving and that metacognitive awareness explains $13 \%$ of the total variance in the variable of beliefs about mathematical problem solving. As a result of this finding, it can be said that improving the metacognitive awareness of pre-service primary school teachers can make some contributions to the development of their beliefs about mathematical problem solving. Therefore, the metacognitive awareness of pre-service primary school teachers should be developed. Yıldırım and Ersözlü ( $\underline{2013}$ ) found that metacognitive awareness predicts university students' problem solving levels significantly and that metacognitive awareness explains $45 \%$ of the variance in their problem solving levels. Baş, Özturan-Sağırlı and Bekdemir (2016) also found that there is a significant and 
positive relationship between metacognitive awareness, attitudes and beliefs towards problem solving, and beliefs and attitudes towards problem solving explain 8\% of metacognitive awareness Moreover, the effect of metacognitive awareness in the formation of beliefs about mathematical problem solving should be taken into consideration.

\section{Conclusion}

This research was conducted in order to reveal the metacognitive awareness and problem solving beliefs of pre-service primary school teachers. As a result of the present study, the pre-service primary school teachers' metacognitive awareness was found to be high and their beliefs about mathematical problem solving were found to be medium. The pre-service primary school teachers' metacognitive awareness was found to be not varying significantly depending on gender while their beliefs about mathematical problem solving were found to be varying significantly depending on gender in favor of the male pre-service teachers. A positive, medium and significant correlation was found between the preservice primary school teachers' metacognitive awareness and beliefs about mathematical problem solving and that metacognitive awareness significantly predicts the variable of beliefs about mathematical problem solving.

Future research can be conducted on different study groups such as primary school teachers and primary school students. Within the context of the primary school math classes, activities to support the development of metacognitive awareness can be conducted to foster primary school students' beliefs about mathematical problem solving. During the undergraduate education of pre-service teachers, they can be provided with opportunities to encounter activities supporting the development of their metacognitive awareness so that their beliefs about mathematical problems solving can be positively affected.

\section{Acknowledgment}

We would like to express sincere gratitude to pre-service primary school teachers studying at the Department of Primary Education in education faculty who have participated in this research. This research study was partly presented as an oral presentation at USEAS 2017, International Limitless Education and Research Symposium held in Alanya, Antalya-Turkey on April, 24-26, 2017.

\section{Bibliography}

Abrosse, R., Clement, L., Philipp, R., \& Chauvot, J. (2004). Assessing prospective elementary school teachers" beliefs about mathematics and mathematics learning: Rationale and development of a Constructed-Response-Format Belief Survey. School Science and Mathematics Journal, 104(2), 56-69. https://doi.org/10.1111/j.19498594.2004.tb17983.x

Akın, A. \& Abacı, R. (2011). Biliş ötesi [Metacognition]. Ankara: Nobel Yayınları

Akın, A., Abacı, R. \&Çetin, B. (2007). The Validity and Reliability of the Turkish Version of the Metacognitive Awareness Inventory. Educational Sciences: Theory \& Practice, 7(2), 655-680. $\quad$ https://toad.halileksi.net/sites/default/files/pdf/bilisotesi-farkindalikenvanteri-toad.pdf

Altun, M. (2008). Eğitim fakülteleri ve sınıf öğretmenleri için matematik öğretimi[Teaching maths to education faculty and primary school teachers]. Ankara: Alfa Yayıncllık

Baker, L. \& Brown, A. L. (1980). Metacognitive skills and reading. Handbook of Reading Research, New York: Longman. 
Baki, A. (2018). Matematiği öğretme bilgisi [The knowledge of teaching maths]. Ankara: Pegem Akademi.

Baş, F., Özturan-Sağırlı, M., \& Bekdemir, M. (2016). The metacognitive awarenesses of preservice secondary school mathematics teachers, beliefs, attitudes on problem solving, and relationship between them. Journal of Theory and Practice in Education, 12(2), 464-482. https://dergipark.org.tr/tr/download/article-file/262376

Baydar, C. ve Bulut. S. (2002). Öğretmenlerin matematiğin doğası ve öğretimi ile ilgili inançlarının matematik eğitimindeki önemi. Hacettepe Üniversitesi Eğitim Fakültesi Dergisi, 23, 62-66. https://dergipark.org.tr/tr/pub/hunefd/issue/7815/102626

Baykara, K. (2011). A study on "teacher efficacy perceptıons" and "metacognitive learning strategies" of prospective teachers. Hacettepe University the Journal of Education, 40, 80-92. http://efdergi.hacettepe.edu.tr/yonetim/icerik/makaleler/396-published.pdf

Baykul, Y. (2016). Illkokulda matematik öğretimi [Teaching maths in primary school].(13rd edition). Ankara: Pegem Akademi.

Baysal, Z. N., Ayvaz, A., Çekirdekçi, S., and Malbeleği, F. (2013). An analysis of metacognitive awareness of pre-service primary school teachers in terms of various variables. Marmara University Atatürk Education Faculty Journal of Educational Sciences, 37, 6881. https://dergipark.org.tr/tr/download/article-file/2153

Belet, S. D., and Güven, M. (2011). Meta-cognitive strategy usage and epistemological beliefs of primary school teacher trainees. Educational Sciences: Theory and Practice, 11(1), 51-57. https://files.eric.ed.gov/fulltext/EJ919889.pdf

Büyüköztürk, Ş. (2012). Sosyal bilimler için veri analizi el kitabı istatistik, araștırma deseni SPSS ugulamalarl ve yorum [Data analysis handbook for social sciences: Statistics, research design, SPSS applications and interpretation]. Ankara: Pegem Akademi.

Byron, M.K. (1995). Confronting the Verbal/Visual Issue: The Mathematical problem-solving processes of a small group of female junior secondary students. Unpublished Doctoral Thesis, The Ohio State University, Ohio, USA.

Charles, R., and Lester, F. (1982). Teaching problem solving: What, why and how. Palo Alto, California: Dale Seymour Publications.

Cüceloğlu, D. (2012). Insan ve davranışı [Human behavior]. İstanbul: Remzi Kitabevi.

Çeliköz, N., Erişen,Y. and Şahin, M. (2012). Bilişsel öğrenme kuramları [Cognitive learning theories]. In Kaya, Z. (Ed.), Öğrenme ve öğretme kuramlar-yaklaşımlar-modeller [Learning and teaching theories-approaches-models] (pp. 49-74). Ankara: Pegem Akademi Yayınları

Çubukçu, Z. (2011). Düşünme becerileri [Thinking skills]. In Filiz, S.B. (Ed.), Öğrenme ögretme kuram ve yaklaşımları [The theories and approaches of learning and teaching](s. 279-334). Ankara: Pegem Akademi Yayınları

Dağll, A. (2004). Problem solving and decision making. Electronic Journal of Social Science, 3(7), 41-49. https://dergipark.org.tr/tr/pub/esosder

Davis, R.B. (1984). Learning mathematics: The cognitive science approach to mathematics education. New Jersey: Ablex Publishing Corporation

Desoete, A., Roeyers, H. \& Buysse, A. (2001). Metacognition and mathematical problem solving in grade 3. Journal of Learning Disabilities 34(5): 435-449. https://doi.org/10.1177/002221940103400505

Demirsöz, E. S. (2014). Metacognitive awareness and its developing. Trakya University Journal of Education, 4, 112-123. https://dergipark.org.tr/tr/download/article$\underline{\text { file } / 200398}$

Deniz, D., Küçük, B., Cansız, Ş., Akgün, L. and İşleyen, T. (2014). Examining metacognitive awareness of prospective secondary school mathematics teachers in terms of some 
variables. Kastamonu Education Journal, 22(1), 305-320. https://dergipark.org.tr/tr/download/article-file/209952

Deringöl, Y. (2018). An analysis of prospective primary school teachers' problem solving beliefs and problem posing self-efficacy beliefs. Turkish Journal of Computer and Mathematics Education, 9(1), 31-53. https://doi.org/10.16949/turkbilmat.336386

Deryakulu, D. (2004). Epistemolojik inançlar. In Y. Kuzgun, and D. Deyakulu (Ed.), Eğitimde bireysel farklılıklar (pp. 259-287). Ankara: Nobel Akademik Yayıncılık.

Dilci, T. and Kaya, S. (2012). Examination of meta-cognitive awareness levels of primary school teachers teaching 4 th and 5 th grades in terms of various variables. SDU Faculty of Arts and Sciences Journal of Social Sciences, 247-267. https://dergipark.org.tr/tr/download/article-file/117833

Duatepe-Paksu, A. (2008). Comparing teachers' beliefs about mathematics in terms of their branches and gender. Hacettepe University Journal of Education, 35, 87-97. https://dergipark.org.tr/tr/pub/hunefd/issue/7803/102277

Erbaş, A. A., Karaduman, G. B. \& Yavuz, G. (2018). The investıgatıon of the relatıonshıp between the primary school teacher candidates' cognitıve levels, creatıvity levels and problem solving skills. Turkish Stuedies, 13, 551-568. https://doi.org/10.7827/TurkishStudies.12816

Flavell, J. H. (1979). Metacognition and cognitive monitoring: A new area of cognitive developmental inquiry. American Psychologist, 34(10), 906-911. https://doi.org/10.1037/0003-066X.34.10.906

Frykholm, J. (2003). Teachers' Tolerance for Discomfort: Implications for Curricular Reform in Mathematics, Journal of Curriculum and Supervision, 19(2), 125-149. http://www.ascd.org/publications/jcs/winter2004/Teachers'-Tolerance-forDiscomfort@-Implications-for-Curricular-Reform-in-Mathematics.aspx

Gelbal, S. (1991). Problem çözme. Hacettepe Üniversitesi Eğitim Fakültesi Dergisi, 6(6), 167-173. https://dergipark.org.tr/tr/pub/hunefd/issue/7831/103054

Grouws, D. A. (1996). Critical İssues in Problem Solving İnstruction in Mathematics. In D. Zhang, T. Sawada, \& J. P. Becker (Eds.), Proceedings of the China-Japan-U.S. seminar on mathematical education (70-93). Carbondale, IL: Board of Trustees of Southern Illinois University.

Gül, Ş., Köse, E. Ö., \& Yılmaz, S. S. (2014). Compared to different variables of prospective biology teachers' metacognitive awareness. HAYEF: Journal of Education, 12-1(23), 83-91. https://dergipark.org.tr/tr/download/article-file/93203

Gülten, D. Ç. \& Soytürk, İ. (2012). An investigation of primary school mathematics teacher candidates' mathematical problem solving beliefs through some variables. The Journal of Academic Social Science Studies, 5(8), 641-656. https://arastirmax.com/tr/system/files/dergiler/79201/makaleler/5/8/arastrmx 7 9201 5 pp 641-656.pdf

Haciömeroğlu, G. (2011a). Turkish adaptation of beliefs about mathematical problem solving instrument . Dicle University Journal of Ziya Gökalp Faculty of Education, 17, 119-132. https://dergipark.org.tr/en/download/article-file/787037

Hacıömeroğlu, G. (2011b). Examining elementary pre-service teachers' epistemological beliefs as predictors of beliefs about mathematical problem solving. Buca Faculty of Education Journal, 30, 206-220. https://dergipark.org.tr/tr/download/articlefile/231663

Heppner, P. P. \& Peterson, C. H. (1982). The development and implications of a personal problem solving inventory. Journal of Counseling Psychology, 29, 66- 75. https://doi.org/10.1037/0022-0167.29.1.66 
House, J. D. (2006). Mathematics beliefs and achievement of elementary school students in Japan and the United States: results from the third international mathematics and science study. The Journal of Genetic Psychology, 167(1), 31-45. https://doi.org/10.3200/GNTP.167.1.31-45

Izgar, H., Gürsel, M., Kesici, Ș. and Negiş, A. (2004). Önder davranışlarının problem çözme becerisine etkisi [The effect of leader behaviors on problem solving skills].. XIII. Ulusal Eğitim Bilimleri Kurultayı, İnönü Üniversitesi Eğitim Fakültesi, Malatya, Turkey.

Kana, F. (2015). Motivational, cognitive and metacognitive competences of pre-service Turkish language teachers. The Journal of International Education Science, 2(4), 395407. https://dergipark.org.tr/tr/download/article-file/562689

Kapa, E. (2001). A metacognitive support during the process of problem solving in a computerized environment. Educational Studies in Mathematics, 47, 317-336. https://link.springer.com/content/pdf/10.1023/A:1015124013119.pdf

Karasar, N. (2014). Bilimsel araştırma yöntemi [Scientific research methods](26 ${ }^{\text {th }}$ edition).Ankara: Nobel Akademik Yayıncllık.

Kayaaslan, A. (2006). 4th and 5th grade elementary school students' beliefs about the nature of mathematics and the teaching of mathematics. Unpublished Master Thesis, Gazi University, Institute of Education Sciences, Ankara, Turkey.

Kayan, F., \& Çakıroğlu, E. (2008). Pre-service elementary mathematics teachers' mathematical problem solving beliefs. Hacettepe University The Journal Of Education (35), 218-226. https://dergipark.org.tr/tr/pub/hunefd/issue/7803/102288

Kışkır, G. (2011). Investigation of the relationship between metacognitive awareness levels and problem solving skills of prospective teachers. Unpublished Master Thesis, Atatürk University, Institute of Education Sciences, Erzurum, Turkey.

Kloosterman, P., \& Stage, F. K. (1992). Measuring beliefs about mathematical problem solving. School Science and Mathematics, 92(3), 109-115. https://doi.org/10.1111/j.1949-8594.1992.tb12154.x

Kramarski, B., Mevarech, Z.R. \& Arami, M. (2002). The effects of metacognitive instruction on solving mathematical authentic tasks. Educational Studies in Mathematics, 49, 225250. https://www.jstor.org/stable/3483076

Krulik, S. \& Rudnick, J.A. (1996). The new sourcebook for teaching reasoning and problem solving in junior and senior high school. Boston: Allyn \& Bacon.

Lai, A. F. \& Yang, S. M. (2011). The learning effect of visualized programming learning on 6 th graders' problem solving and logical reasoning abilities. Electrical and Control Engineering (ICECE), 2011 International Conference on. IEEE.

Lin, X., Schwartz, D. L., \& Hatano, G. (2005). Toward teachers' adaptive metacognition. $\begin{array}{lll}\text { Educational } \quad \text { Psychologist, } & \text { 240(4), }\end{array}$ https://doi.org/10.1207/s15326985ep4004 6

Lloyd, G., and Wilson, S. (1998). Supporting innovation: The impact of a teacher's conceptions of functions on his implementations of a reform curriculum. Journal for Research in Mathematics Education, 29(3), 248-274. https://doi.org/10.2307/749790

Mason, L., and Scrivani, L. (2004). Enhancing students' mathematical beliefs: An intervention study. Learning and Instruction, 14, 153176. https://doi.org/10.1016/j.learninstruc.2004.01.002

McLeod, D. (1992). Research on affect in mathematics education: A reconceptualization. In D. Grouwsm (Ed.), Handbook of research on mathematics teaching and learning (pp. 575-596). New York: Macmillan.

McLeod, D. B., \& McLeod, S. H. (2002). Synthesis - beliefs and mathematics education: Implications for learning, teaching, and research. In G. C. Leder, E. Pehkonen, and G. 
Törner (Ed.), Beliefs: A hidden variable in mathematics education? (pp. 115-127). Dordrecht: Kluwer Acedemic.

Memnun, D. S., \& Akkaya, R. (2012). An investigation of pre-service primary school mathematics, science and primary school teachers' metacognitive awareness in terms of knowledge of and regulation of cognition. Journal of Theoretical Educational Science, 5(3), 312-329.https://dergipark.org.tr/tr/pub/akukeg/issue/29346/314038

Montague, M., Applegate, B. \& Marquard, K. (1993). Cognitive strategy instruction and mathematical problem-solving performance of students with learning disabilities. Learning Disabilities Research and Practice, 8(4), 223-232. https://doi.org/10.1177/002221949703000204

Morgan, J., and Williams, B. C. (2007). Overview of problem solving. In S. W. Beyerlein, C. Holmes, and D. K. Apple (Eds.), Faculty guidebook: A comprehensive tool for improving facultyperformance (pp. 181-184). Lisle, IL: Pacific Crest.

Özkubat, U. \& Özmen, E.R. (2020). Turkish adaptation of the metacognitive experiences questionnaire in solving math problems. OPUS International Journal of Society Researches, 16(31), 3958-3984. https://doi.org/10.26466/opus.736793

Özsoy, G. (2014). The Relationship Between Problem Solving Skills and Mathematical Achievement. Gazi UniversityJournal of Gazi Education Faculty, 25(3), 179-190. http://www.gefad.gazi.edu.tr/tr/download/article-file/77235

Özsoy, G. and Günindi, Y. (2011). Prospective preschool teachers' metacognitive awareness. Elementary Education Online, 10(2),430-440. https://www.ilkogretimonline.org/fulltext/218-1596869645.pdf?1618759255

Özturan-Sağırlı, M., Baş, F. \&Bekdemir, M. (2020). The Relationship between teacher candidates' metacognitive awareness levels and achievements. Journal of BayburtEducation Faculty, 15(29), 1-22. https://doi.org/10.35675/befdergi.464806

Öztürk, S., \&Serin, M. K. (2020). Examination of pre-service primary school teachers' metacognitive awareness with anxiety towards mathematics teaching. Kastamonu Education Journal, 28(2), 1013-1025. https://doi.org/10.24106/kefdergi.705074

Pajares, M. F. (1992). Teachers' beliefs and educational research: Cleaning up a messy construct. Review of Educational Research, 62(3), 307-332. https://doi.org/10.3102/00346543062003307

Polya G.. (1957). How to solve it: A new aspect of mathematical method. Ed. ke-2. New Jersey: Princeton University Press.

Polya, G. (1981). Mathematical discovery: On understanding, learning, and teaching problem solving. New York: John Wiley.

Posamentier, A. S. \& Krulik, S. (2016). Matematikte problem çözme [Problem solving in mathematics](L. Akgün, T. Kar and M. F. Öçal, Trans.). Ankara: Pegem Akademi.

Raymond, A. M. (1997). Inconsistency between a beginning elementary school teacher's mathematics beliefs and teaching practices. Journal for Research in Mathematics Education, 28(6), 550-576. https://doi.org/10.2307/749691

Reeve, R. A., \& Brown, A. L. (1985). Metacognition reconsidered: Implications for intervention research. Journal of Abnormal Child Psychology, 13(3), 343356.https://doi.org/10.1007/BF00912721

Sağlam, Y. \& Dost, S. (2014). Preservice science and mathematics teachers' beliefs about mathematical problem solving. Procedia-Social and Behavioral Sciences, 116, 303-306. https://doi.org/10.1016/i.sbspro.2014.01.212

Schoenfeld, A. H. (1985). Mathematical problem solving (1st edition). Orlando: Academic Press. 
Schoenfeld, A. H. (1989). Explorations of students' mathematical beliefs and behavior. Journal for Research in Mathematics Education, 20(4), 338-355. https://doi.org/10.2307/749440

Schraw, G. (1998). Promoting general metacognitive awareness. Instructional Science, 26, 113-125. https://doi.org/10.1023/A:1003044231033

Schraw, G. \& Dennison, R.S. (1994). Assessing metacognitive awareness. $\begin{array}{lll}\text { Contemporary Educational } \quad \text { Psychology, } & \text { 460-475), }\end{array}$ https://doi.org/10.1006/ceps.1994.1033

Schraw, G. and Moshman, D., (1995). Metacognitive theories. Educational Psychology Review, 7(4), 351-371. https://doi.org/10.1007/BF02212307

Schunk, D. H. (2009). Öğrenme teorileri eğitimsel bir bakışla [Learning theories: An educational perspective](M. Şahin, Trans.). Ankara: Nobel Yayın Dağıtım.

Schunk, D. H. (1989). Self-efficacy and achievement behaviors. Educational Psychology Review, 1,173-208. https://doi.org/10.1007\%2FBF01320134

Silik, Y. (2016). Effect of educational robotics applications on problem solving skills of science teacher candidates. Unpublished Master Thesis, Karadeniz Technical University, Institute of Education Sciences, Trabzon, Turkey.

Smith, E., E. \& Kosslyn, S.M. (2014). Bilişsel psikoloji [Cognitive psychology](Şahin, M., Trans.)Ankara: Nobel Akademik Yayınları

Stillman, G.A. \& Galbraith, P.L. (1998). Applying mathematics with real world connections: metacognitive characteristics of secondary students. Educational Studies in Mathematics, 36, 157-195. https://www.jstor.org/stable/3482790

Stylianou, D.A. (2002). On the interaction of visualization and analysis: the negotiation of a visual representation in expert problem solving. Journal of Mathematical Behavior, 21, 303- 317. https://doi.org/10.1016/S0732-3123(02)00131-1

Soytürk, İ. (2011). An investigation of pre-service primary school teachers' self-efficacy about mathematical literacy and their beliefs about mathematical problem solving. Unpublished Master Thesis, İstanbul University, Social Sciences Institute, İstanbul, Turkey.

Thompson, A. G. (1992). Teachers' belief and conceptions: A synthesis of the research. In D. A. Grouws (Ed.), Handbook of research on mathematics teaching and learning (pp. 12146). New York: Macmillan.

Toptaş, V. \& Gözel, E. (2017). Beliefs and the mathematical problem solutions of primary school teacher candidates. Kirlkkale University Journal of Social Sciences, 7(2), 439459. https://dergipark.org.tr/tr/download/article-file/338040

Tunçer, B. K. (2013). The relationship between pre-service teachers' academic achievement toward initial reading writing course, metacognitive awareness level, thinking style and attitudes toward course. Unpublished Master Thesis, Çanakkale 18 Mart University, Institute of Education Sciences, Çanakkale, Turkey.

Ünlü, M. \& Sarpkaya Aktaş, G. (2016). Pre-service elementary mathematics teachers' selfefficacy beliefs about problem posing and beliefs about problem solving. Abant Izzet Baysal University Journal of Faculty of Education, 16(4), 2040-2059. https://dergipark.org.tr/tr/download/article-file/291960

Wilkins, J., \& Brand, B. (2004). Change in pre-service teachers' beliefs: An evaluation of a mathematics methods course. School Science \& Mathematics, 104(5), 226232. https://doi.org/10.1111/i.1949-8594.2004.tb18245.x

Wilson, N. S., \&Bai, H. (2010).The relationships and impact of teachers' metacognitive knowledge and pedagogical understandings of metacognition. Metacognition and Learning, 5(3), 269-288. https://doi.org/10.1007/s11409-010-9062-4 
Van De Walle, J. A., Karp, K. S. \& Bay-Williams, J. M. (2016). Problem çözme ile öğretim [Teaching through problem solving] (S. Durmuş, Trans.). In S. Durmuş (Ed.), Illkokul ve ortaokul matematiği [Elementary and middle school mathematics] (pp. 32-57). Ankara: Nobel Kitap.

Yavuz, G. \& Erbay, H. N. (2015). The analysis of pre-service teachers' beliefs about mathematical problem solving. Procedia - Social and Behavioral Sciences, 174, 2687 2692. https://doi.org/10.1016/j.sbspro.2015.01.953

Yıldırım, S. \& Ersözlü, Z. N. (2013). The relationship between students' metacognitive awareness and their solutions to similar types of mathematical problems. Eurasia Journal of Mathematics, Science and Technology Education, 9(4), 411-415. https://doi.org/10.12973/eurasia.2013.946a 